\title{
Fermentasi Kelapa Parut Bebas Protein dengan Aspergillus niger untuk Menghasilkan Lipase
}

\section{[Fermentation of Protein-Free Grated Coconut with Aspergillus niger to Produce of Lipase]}

\author{
Rifka Aulia ${ }^{1^{*}}$, Syaiful Bahri ${ }^{1}$, Meryany Ananda ${ }^{2}$ \\ ${ }^{1)}$ Jurusan Kimia, Fakultas MIPA, Universitas Tadulako, Jl. Soekarno Hatta Km.9, Kampus Bumi Tadulako Tondo Palu \\ 2) Jurusan Biologi, Fakultas MIPA, Universitas Tadulako, Jl. Soekarno Hatta Km.9, Kampus Bumi Tadulako Tondo Palu \\ *)Coresponding author: rifka_aulia@ymail.com
}

\begin{abstract}
The research about the fermentation of protein-free grated coconut with Aspergillus niger to produce of crude lipase enzyme has been carried out. This study aims to determine the effect of water content on fermentation medium and the incubation time which results lipase enzyme extract with the highest activity. This study used a Completely Randomized Design (CRD) consisting of 2 factors, i.e. variations of water content in medium of $40 \%, 50 \%, 60 \%$, and $70 \%$ and incubation times of 48, 96, 144, and 192 hours. The parameters observed were lipase enzyme activity produced in each treatment. The results showed that the highest medium water content was $70 \%$ with the lipase enzyme activity $4.33 \mu \mathrm{mol} / \mathrm{mL}$.minute and the best incubation time was 96 hours with the lipase enzyme activity of $0.83 \mu \mathrm{mol} / \mathrm{mL}$.minute.
\end{abstract}

Keywords: Lipase enzyme, protein-free grated coconut, Aspergillus niger

ABSTRAK. Telah dilakukan penelitian tentang fermentasi kelapa parut bebas protein dengan Aspergillus niger untuk menghasilkan ekstrak kasar enzim lipase. Penelitian ini bertujuan untuk menentukan pengaruh kadar air medium fermentasi dan waktu inkubasi yang menghasilkan ekstrak enzim lipase dengan aktivitas tertinggi. Penelitian ini meggunakan Rancangan Acak Lengkap (RAL) yang terdiri dari 2 faktor, yaitu variasi kadar air medium 40\%, 50\%, 60\%, dan 70\% dan waktu inkubasi 48, 96, 144 dan 192 jam. Parameter yang diamati adalah aktivitas enzim lipase yang dihasilkan pada setiap perlakuan. Hasil penelitian menunjukkan bahwa kadar air medium tertinggi $70 \%$ dengan aktivitas enzim lipase $4,33 \mu \mathrm{mol} / \mathrm{mL}$.menit dan waktu inkubasi tertinggi 96 jam dengan aktivitas enzim lipase $0,83 \mu \mathrm{mol} / \mathrm{mL}$.menit.

Kata Kunci : Enzim lipase, kelapa parut bebas protein, Aspergillus niger

Riwayat artikel: Diterima 2 Juli 2019, Disetujui 12 April 2020

Cara sitasi: Aulia, R., Bahri, S., Ananda, M. (2020). Fermentasi Kelapa Parut Bebas Protein dengan Aspergillus niger untuk Menghasilkan Lipase. KOVALEN: Jurnal Riset Kimia, 6(1): 45-52.

DOI: https://doi.org/10.22487/kovalen.2020.v6.i1.13052

\section{LATAR BELAKANG}

Kelapa merupakan salah satu jenis tumbuhan yang cukup tinggi kadar lipidnya, sehingga banyak dimanfaatkan untuk produksi minyak. Menurut Prihatini (2008), kandungan lemak kelapa tergantung pada umur kelapanya. Semakin tua kelapa, kandungan lemaknya semakin tinggi. Produk dengan nilai ekonomis tinggi yang digunakan diberbagai proses industri pangan maupun nonpangan dapat dihasilkan melalui proses reaksi antara enzim dengan molekul substrat yang ditemukan pada hewan, tumbuhan, dan mikroorganisme. 
Tingginya kandungan lipid pada buah kelapa, sehingga dapat pula dimanfaatkan untuk menghasilkan enzim lipase. Substrat yang umum digunakan untuk memproduksi enzim lipase adalah substrat yang mengandung lemak, seperti santan kelapa (Mappiratu, 1997), bungkil inti sawit (Pasaribu et al., 1998), dan kelapa parut (Indah et al., 2017). Enzim lipase dapat diproduksi melalui reaksi-reaksi esterifikasi, alkoholisis, asidolisis dan aminolisis (Gandhi, 1997) serta hidrolisis triasilgliserol (TAG) menghasilkan diasilgliserol (DAG) dan asam lemak bebas (Putranto et al., 2006). Enzim lipase dapat dihasilkan dengan cara fermentasi menggunakan kapang Aspergillus niger (Prabaningtyas et al., 2018). Jenis kapang ini selain dapat menghasilkan enzim lipase, juga dapat menghasilkan enzim lainnya, seperti selulase, protease, xilanase, dan mananase.

Produksi enzim lipase menggunakan Aspergillus niger penting karena kapang Aspergillus niger merupakan mikroorganisme yang mampu menghasilkan enzim lipase dengan aktivitas tinggi dan mudah didapatkan. Produksi enzim lipase sangat dipengaruhi oleh $\mathrm{pH}$, suhu, kadar air, jenis substrat dan waktu fermentasi. Fermentasi kelapa parut dari Aspergillus niger untuk menghasilkan lipase dipengaruhi oleh komponen kimia yang terdapat dalam substrat. Untuk mengefektifkan produksi lipase, komponen yang terdapat dalam substrat dapat dikurangi dengan cara penambahan larutan $\mathrm{NaOH}$ (deproteinasi) (Purkan et al., 2016) untuk membebaskan protein sehingga jumlah enzim lipase yang dihasilkan meningkat dan diperoleh enzim dengan aktivitas yang lebih tinggi.

Indah et al. (2017) telah memproduksi enzim lipase menggunakan Aspergillus niger isolat kapang kopra memanfaatkan medium kelapa parut dan menghasilkan aktivitas enzim lipase tertinggi $1,70 \mu \mathrm{mol} / \mathrm{ml}$.menit selama 48 jam fermentasi pada pH 7. August (2000) dalam produksi lipase menggunakan substrat minyak kelapa, memperoleh aktivitas enzim lipase 5,042 $\mu \mathrm{mol} / \mathrm{ml}$.menit selama 6 hari fermentasi pada $\mathrm{pH}$ 7. Perbedaan waktu fermentasi disebabkan oleh perbedaan kemampuan mikroorganisme dalam mendegradasi komponen-komponen nutrisi yang terdapat dalam substrat (August, 2000).

Dalam proses fermentasi menggunakan fasa padat, kadar air pada medium berpengaruh terhadap jumlah enzim lipase yang dihasilkan. Air berfungsi dalam metabolisme organisme, yaitu sebagai sumber oksigen dan hidrogen dalam biosintesis komponen sel dan sebagai transportasi nutrisi. Jumlah air yang dibutuhkan dalam fermentasi menggunakan fasa padat berbeda-beda tergantung jenis organisme dan substrat yang digunakan. Menurut Zaks \& Klibanov (1984), jumlah air minimum yang dibutuhkan oleh enzim untuk dapat melakukan aktivitasnya adalah sekitar $50 \%$ dari jumlah air yang dibutuhkan untuk membentuk selapis (monolayer) molekul air yang menutup permukaan protein. Faktor kadar air dan waktu fermentasi menjadi variabel utama pada produksi enzim lipase dari Aspergillus niger menggunakan kelapa parut bebas protein dengan tujuan menghasilkan aktivitas lipase yang tinggi.

\section{METODE PENELITIAN}

\section{Bahan dan Peralatan}

Bahan utama yang digunakan, yaitu kelapa parut, minyak kelapa merk Sunco, kultur murni Aspergillus niger, kentang, gula, media 
PDA, PDB, indikator PP, buffer fosfat $(\mathrm{pH} 6$ dan 7), selenium, $\mathrm{H}_{2} \mathrm{SO}_{4}$ (pa), urea, $\left(\mathrm{NH}_{4}\right)_{2} \mathrm{SO}_{4}$, $\mathrm{KH}_{2} \mathrm{PO}_{4}, \quad \mathrm{MgSO}_{4} .7 \mathrm{H}_{2} \mathrm{O}, \mathrm{CaCl} . \mathrm{H}_{2} \mathrm{O}, \mathrm{Na}_{2} \mathrm{CO}_{3}$, $\mathrm{CuSO}_{4} \cdot 5 \mathrm{H}_{2} \mathrm{O}$, aseton, etanol, $\mathrm{CaCl}_{2}, \mathrm{NaOH}$, dan akuades.

Peralatan yang digunakan, yaitu alat parut, oven, desikator, neraca analitik Ohaus Corp. Pine Brook, soxhlet, Labu kjehdahl, kompor destruksi Gerhardt, ayakan, mikropipet, botol semprot, termoshaker Gerhardt, pipet tetes, termometer, autoklaf Hirayama, jarum ose, klem dan statif, buret, serta bunsen.

\section{Prosedur Penelitian}

\section{Pembuatan kelapa parut bebas protein}

Kelapa parut yang telah dikeringkan ditambahkan larutan $\mathrm{NaOH} 5 \%$ pada perbandingan 1:10 (b/v). Kemudian disaring dan dicuci menggunakan akuades sampai $\mathrm{pH}$ netral. Lalu dikeringkan dengan oven pada suhu $105^{\circ} \mathrm{C}$ selama 10 jam (Purkan et al., 2016). Residu kelapa parut yang diperoleh diukur kadar protein (metode Kjehdahl) dan kadar lemak (metode sokletasi) sebelum dan sesudah dibebaskan protein.

\section{Perbanyakan Aspergillus murni pada media PDA}

Alat-alat yang akan digunakan dalam perbanyakan ini disterilkan terlebih dulu, dengan cara membungkus cawan petri menggunakan kertas kemudian disterilisasi selama 30 menit dengan suhu $121^{\circ} \mathrm{C}$. Setelah disterilkan cawan petri diisi dengan media PDA (Potato Dextrose Agar) sebanyak $1,17 \mathrm{ml}$. Setelah itu cawan petri dibiarkan agar medianya menjadi padat selama 3-4 jam. Setelah media menjadi padat, dilakukan proses inokulasi dengan menggunakan metode gores. Teknik dalam inokulasi yaitu mengambil Aspergillus niger murni dengan jarum ose dan dipindahkan ke dalam media padat (PDA). secara zig-zag dari atas ke bawah. Kemudian diinkubasi selama 3-7 hari.

\section{Perbanyakan Aspergillus murni pada media produksi PDB}

Kentang dikupas kemudian dipotong dadu, lalu dimasukkan di dalam air dan dipanaskan hingga lunak. Setelah itu disaring, kemudian diambil filtratnya $100 \mathrm{~mL}$ ditambahkan gula $2 \mathrm{~g}$ ke dalam erlenmeyer $250 \mathrm{~mL}$. Kemudian suspensi jamur ditambahkan secara steril, kemudian dishaker selama 3-7 hari.

\section{Penentuan jumlah sel Aspergillus niger menggunakan hemasitometer}

Koloni Aspergillus niger diencer 10x, kemudian dipipet menggunakan mikropipet $1 \mu \mathrm{L}$ pada parit kaca pada alat hitung. Diletakkan alat hitung pada meja benda dan kemudian diamati menggunakan mikroskop dengan perbesaran lensa objektif lensa 40x. Dihitung jumlah spora secara kasar dengan menghitung 5 kotak sedang dan dirata-ratakan.

\section{Produksi enzim lipase}

Sejumlah $20 \mathrm{~g}$ kelapa parut kering bebas protein dimasukkan dalam erlenmeyer $500 \mathrm{~mL}$ kemudian ditambahkan buffer posfat $\mathrm{pH} 7$ yang berisi larutan nutrisi (urea 0,75 g/L, $\left(\mathrm{NH}_{4}\right)_{2} \mathrm{SO}_{4}$ $2,5 \mathrm{~g} / \mathrm{L}, \quad \mathrm{KH}_{2} \mathrm{PO}_{4} \quad(0,75 \mathrm{~g} / \mathrm{L}), \quad \mathrm{MgSO}_{4} .7 \mathrm{H}_{2} \mathrm{O}$ $(0,125 \mathrm{~g} / \mathrm{L})$, dan $\left.\mathrm{CaCl} . \mathrm{H}_{2} \mathrm{O}(0,125 \mathrm{~g} / \mathrm{L})\right)$ dengan variasi rasio air medium $40 \%, 50 \%, 60 \%$, dan $70 \%$ yang mengandung $1 \mathrm{~mL}$ kultur Aspergillus niger. Campuran diaduk hingga homogen dan diinkubasi pada suhu ruang pada waktu inkubasi 48, 96, 144 dan 192 jam. Lipase yang ada dalam medium diekstrak menggunakan $250 \mathrm{~mL}$ larutan $\mathrm{CaCl}_{2} \quad 0,01 \mathrm{M}$. Campuran dikocok selama 1 jam diatas shaker. Selanjutnya disaring dan filtratnya ditampung sebagai larutan enzim lipase (Indah et al., 
2017), kemudian ditentukan aktivitas enzim lipasenya.

\section{Penentuan aktivitas enzim}

Pada penentuan aktivitas enzim, digunakan minyak kelapa sebanyak $2 \mathrm{~g}$, dimasukkan kedalam erlenmeyer bertutup 500 $\mathrm{mL}$, kemudian ditambahkan $4 \mathrm{~mL}$ larutan buffer 0,01 M (pH 6,0), $1 \mathrm{~mL}$ larutan $\mathrm{CaCl} 1 \mathrm{M}$ dan 1 $\mathrm{mL}$ filtrat (larutan enzim). Campuran selanjutnya diinkubasi pada inkubator bergoyang agitasi 300 rpm pada suhu ruang selama 1 jam. Setelah waktu inkubasi tercapai segera substrat enzim diinaktifkan dengan penambahan campuran aseton-etanol $(1: 1 \mathrm{v} / \mathrm{v})$ sebanyak $10 \mathrm{~mL}$. Lalu campuran dibuat homogen dengan pengocokan, kemudian ditambahkan 3 tetes indikator pp dan dititrasi dengan larutan $\mathrm{NaOH} \quad 0,05 \quad M$ sampai campuran berwarna merah jambu. Untuk blanko dilakukan dengan cara yang sama tanpa sampel. Kemudian aktivitas lipase dihitung menggunakan Persamaan 1 (Indah et al., 2017) :

$$
\begin{aligned}
\text { Aktivitas Lipase } & =\frac{(\mathrm{A}-\mathrm{B}) \times \mathrm{N} \mathrm{NaOH} \times 1000}{\mathrm{~V} \times \mathrm{t}} \\
\text { Keterangan : } & \\
\quad \text { Aktivitas lipase } & =\mu \mathrm{mol} / \mathrm{mL} \text {.menit } \\
\mathrm{A} & =\text { volume } \mathrm{NaOH} \text { sampel }(\mathrm{mL}) \\
\mathrm{B} & =\text { volume } \mathrm{NaOH} \text { blanko }(\mathrm{mL}) \\
\mathrm{N} \mathrm{NaOH} & =0,05 \mathrm{~N} \\
1000 & =\text { nilai konversi dari } \mathrm{mmol} \text { ke } \\
& \mu \text { mol } \\
\mathrm{V} & =\text { volume enzim }(\mathrm{mL}) \\
\mathrm{t} & =\text { waktu inkubasi (menit) }
\end{aligned}
$$

\section{HASIL DAN PEMBAHASAN}

\section{Kelapa Parut Bebas Protein}

Kelapa parut yang sudah kering kemudian di bebaskan protein (deproteinasi) dengan penambahan $\mathrm{NaOH}$ 5\%. Deproteinasi adalah proses memisahkan atau menghilangkan kandungan protein terlarut yang terdapat pada suatu bahan. Pada prosesnya, protein akan bereaksi dengan ion $\mathrm{Na}^{+}$dari $\mathrm{NaOH}$ menjadi $\mathrm{Na}$ proteinat yang larut (Ashari, 2018).

Hasil analisis kadar protein sebelum dilakukan penambahan $\mathrm{NaOH} 5 \%$ adalah $6,94 \%$ dan setelah dibebaskan proteinnya $1,82 \%$. Hasil yang diperoleh ini sudah dapat dikatakan bebas protein karena pada bahan masih terdapat senyawa kimia yang mengandung $\mathrm{N}$ seperti purina, pirimidina, vitamin-vitamin, asam amino besar, dan kreatina yang ikut teranalisis dan terukur sebagai nitrogen (Winarno, 2004). Senyawasenyawa tersebut tidak dapat larut dalam $\mathrm{NaOH}$ sehingga ketika dilakukan uji Kjeldahl tetap terbaca nitrogennya.

Hasil analisis kadar lemak kelapa parut awal menggunakan metode soklet yang diperoleh sebesar $19,96 \%$, setelah dilakukan pembebasan protein kadar lemaknya naik menjadi $30,68 \%$. Peningkatan kadar lemak pada kelapa parut diakibatkan oleh adanya sebagian komponen senyawa yang ikut terlarut di dalam $\mathrm{NaOH}$ selain senyawa protein sehingga komponen senyawa pada kelapa parut berkurang dan menyebabkan kadar lemak menjadi naik. Menurut Prihatini (2008), kandungan lemak pada kelapa berdasarkan perbedaan umur buah kelapa adalah 0,9\% (muda), 15\% (setengah tua) dan 34,7\% (tua). Kadar lemak yang diperoleh lebih kecil dibandingkan dengan literatur. Kemungkinan kelapa yang digunakan adalah campuran antara kelapa setengah tua dan kelapa tua.

\section{Hasil Fermentasi}

Pada penelitian ini, produksi enzim menggunakan medium kelapa karena kelapa memiliki lemak yang tinggi. Aspergillus niger digunakan karena mampu menghasilkan enzim lipase dengan baik. Falony et al. (2006) 
menyatakan produksi enzim lipase dengan menggunakan medium lemak sebagai substrat menghasilkan enzim lipase yang lebih spesifik dibandingkan dengan produksi tanpa menggunakan medium lemak.

Jumlah enzim lipase yang dihasilkan pada setiap proses fermentasi akan berbeda hasilnya, tergantung pada kandungan lemak yang terdapat pada media yang berfungsi sebagai substrat.

\section{Jumlah Spora Aspergillus niger}

Kultur Aspergillus niger diremajakan pada media padat PDA (media selektif untuk kapang). Hasil inkubasi selama 3-7 hari pada suhu $37^{\circ} \mathrm{C}$, terbentuk miselium berwarna hijau kehitaman (Gambar 1). Pertumbahan miselium pada hari ke-3 belum maksimal dan mencapai maksimal pada hari ke-7 yang ditandai dengan banyaknya isolat Aspergillus niger yang tumbuh memenuhi cawan petri.

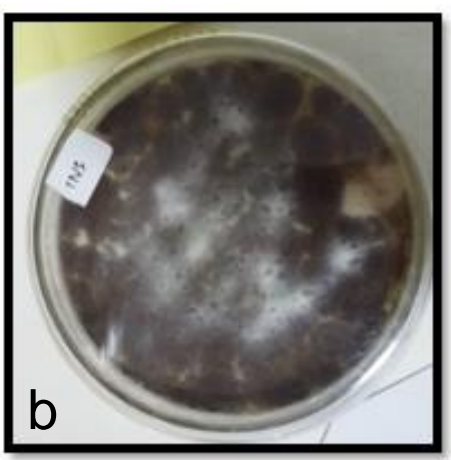

Gambar 1. Biakan Aspergillus niger pada media PDA hari ke-3 (a) dan ke-7 (b)

Miselium yang terbentuk kemudian dipindahkan ke media PDB untuk menghasilkan sel-sel Aspergillus niger yang lebih aktif. Proses pengaktifan sel-sel dilakukan dengan cara aerasi untuk menyuplai oksigen secara terus menerus. Inkubasi dilakukan selama 3-7 hari. Spora Aspergillus niger yang terbentuk sempurna pada hari ke-7 dihitung menggunakan alat Hemasitometer (Gambar 2). Hasil perhitungan spora, diperoleh jumlah spora $9,25 \times 10^{9} \mathrm{sel} / \mathrm{mL}$.
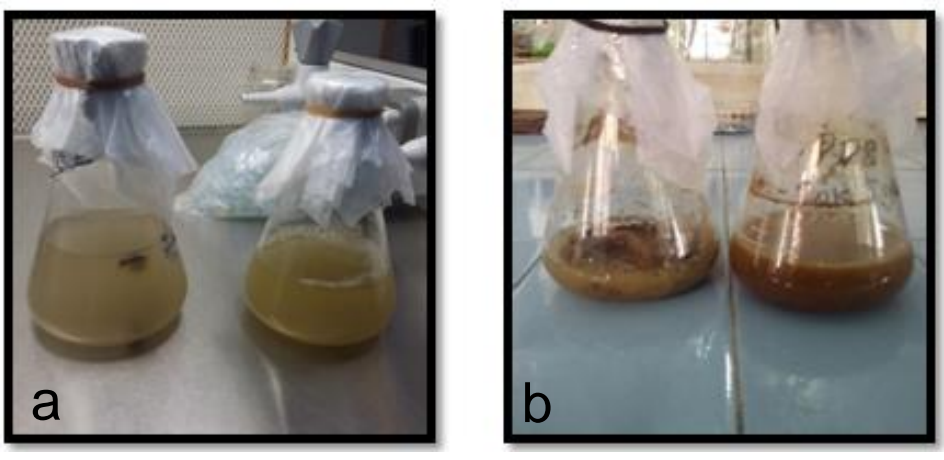

Gambar 2. Biakan Aspergillus niger pada media PDB hari ke-3 (a) dan ke-7 (b)
Aktivitas Inkubasi

\section{Lipase pada Variasi Waktu}
Aktivitas enzim lipase dari kapang
mencapai optimum pada waktu inkubasi 96 jam, yaitu 0,83 $\mu \mathrm{mol} / \mathrm{mL}$.menit (Gambar 3). Aspergillus niger pada proses fermentasi 


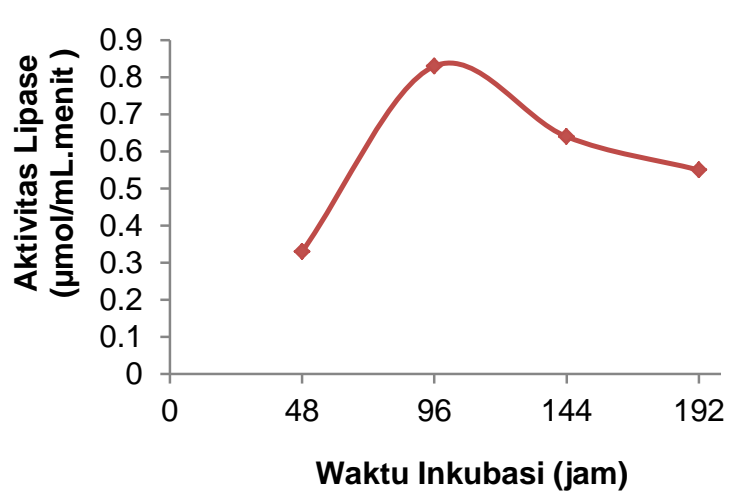

Gambar 3. Aktivitas enzim lipase pada variasi waktu inkubasi

Pada waktu inkubasi 48-96 jam, jumlah nutrisi yang terdapat pada kelapa parut bebas protein mencukupi untuk pertumbuhan Aspergillus niger sehingga jumlah ekstrak enzim yang dihasilkan meningkat dan mengakibatkan aktivitas enzim lipase semakin tinggi. Pada waktu inkubasi 96-192 jam, jumlah nutrisi sudah mulai berkurang dan kemungkinan sebagian dari enzim mengalami kerusakan sehingga jumlah enzim yang terdapat dalam ekstrak semakin berkurang dan mengakibatkan aktivitas enzim lipase juga menurun.

Indah et al. (2017) memperoleh waktu inkubasi terbaik 48 jam pada produksi enzim lipase menggunakan medium kelapa parut, sedangkan Maryanty et al. (2010) memperoleh waktu inkubasi 72 jam dengan aktivitas crude enzim lipase 42,22 U/mL pada konsentrasi Aspergillus niger 50\%. Utami et al., 2017) memperoleh waktu terbaik 120 jam dengan aktivitas 38,67 U/g dalam produksi ekstrak kering ekstraseluler lipase dari Aspergillus niger dengan fase padat substrat dedak padi. Perbedaan hasil aktivitas enzim lipase yang dihasilkan pada variasi waktu inkubasi dan kadar air medium dikarenakan adanya perbedaan perlakuan dan lingkungan yang dapat mempengaruhi pertumbuhan mikroorganisme.

Hasil uji statistik (oneway ANOVA) menghasilkan nilai signifikan 0,178 atau lebih besar dari nilai a 0,05. Hasil yang diperoleh menunjukkan bahwa waktu inkubasi berpengaruh tidak nyata terhadap aktivitas enzim lipase.

\section{Aktivitas Lipase pada Variasi Kadar Air}

Produksi enzim lipase dari kapang Aspergillus niger menggunakan fermentasi padat dipengaruhi oleh beberapa faktor, antara lain seperti kadar air medium, $\mathrm{pH}$ dan waktu inkubasi. Kadar air pada medium pada saat inkubasi dapat diatur dengan menggunakan larutan buffer. Buffer yang digunakan adalah buffer fosfat. Kapang umumnya lebih toleran terhadap suasana asam sampai netral, yaitu pada $\mathrm{pH}$ 3-7. Aspergillus niger mempunyai kisaran $\mathrm{pH}$ untuk tumbuh cukup luas yaitu 2,88,8. Menurut Indah et al. (2017), pH terbaik untuk produksi enzim lipase adalah $\mathrm{pH}$ 7. Pada penelitian ini digunakan buffer fosfat $\mathrm{pH} 7$.

Hasil analisis yang diperoleh adalah aktivitas enzim lipase tertinggi diperoleh pada kadar air $70 \%$ dengan aktivitas enzim lipase 4,33 $\mu \mathrm{mol} / \mathrm{mL}$.menit (Gambar 4).

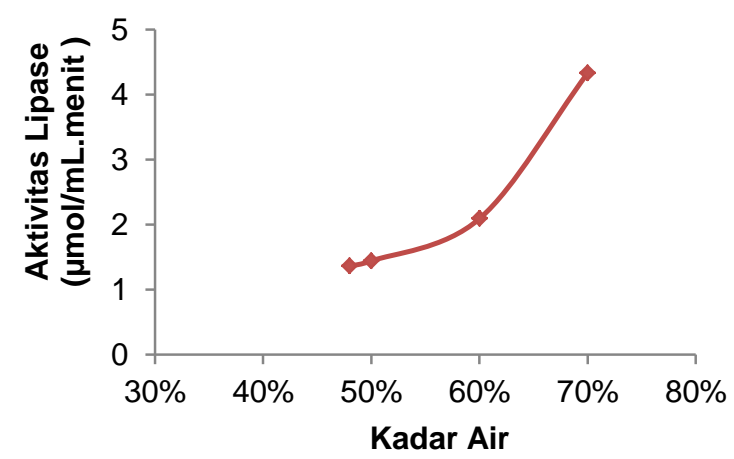

Gambar 4. Aktivitas enzim lipase pada variasi kadar air medium

Penggunaan kadar air lebih dari 70\% tidak digunakan, karena dari beberapa hasil penelitian untuk beberapa jenis mikroba, 
kondisi optimum hanya terjadi pada kisaran kadar air 40\%-70\% (Idiawati et al., 2014). Hasil yang diperoleh berbeda dengan hasil yang diperoleh Indah et al. (2017), yaitu $45 \%$ dengan aktivitas enzim lipase tertinggi yaitu 1,70 $\mu \mathrm{mol} / \mathrm{mL}$.menit pada produksi enzim lipase dari Aspergillus niger menggunakan medium kelapa parut. Falony et al. (2006) memperoleh kadar air optimum 65\% dengan aktivitas enzim 4,8 $\mathrm{IU} / \mathrm{mL}$ untuk produksi lipase ekstraselular dari Aspergillus niger menggunakan kultur mineral dan dedak gandum.

Hasil analisis statistik dengan taraf kepercayaan 95\% (sig $=0,05)$ didapatakan nilai signifikan 0,000 . Hasil yang diperoleh menunjukkan kadar air medium memberi pengaruh nyata terhadap aktivitas enzim lipase. Dilanjutkan pada uji Duncan untuk menentukan kadar air medium terbaik. Kadar air medium $70 \%$ memiliki nilai aktivitas tertinggi dan berbeda nyata dengan perlakuan kadar air lainnya.

\section{KESIMPULAN}

Waktu inkubasi 96 jam mengahasilkan aktivitas enzim lipase tertinggi, yaitu 0,83 $\mu \mathrm{mol} / \mathrm{mL}$.menit. Kadar air medium fermentasi terpilih, yaitu $70 \%$ dengan aktivitas enzim lipase 4,33 $\mu \mathrm{mol} / \mathrm{mL}$.menit. Kadar air sangat berpengaruh terhadap aktivitas enzim lipase dari Aspergillus niger.

\section{DAFTAR PUSTAKA}

Ashari, N. (2018). Produksi Mananase Dari Substrat Ampas Kelapa Bebas Lemak dan Protein Dari Aspergillus niger. [Skripsi]. Jurusan Kimia Universitas Tadulako, Palu.

August, E. (2000). Kajian Lipase Amobil dari Aspergillus niger pada Pembuatan MAG Yang Bersifat Antibakteri dari Minyak
Kelapa. [Skripsi]. Institut Pertanian Bogor, Bogor.

Falony, G., Armas, J. C., Mendoza, J. C. D., \& Hernández, J. L. M. (2006). Production of Extracellular Lipase from Aspergillus niger by Solid-State Fermentation. Food Technol. Biotechnol., 44(2): 235--240.

Gandhi, N. N. (1997). Applications of Lipase. Journal of the American Oil Chemists' Society, $\quad 74(6)$ : 621-634. https://doi.org/10.1007/s11746-997-0194-x

Indah, I., Mappiratu, M., \& Musafira, M. (2017). Produksi Enzim Lipase dari Aspergillus niger Isolat Kapang Kopra dengan Menggunakan Medium Kelapa Parut. KOVALEN, 3(3): 269-276. https://doi.org/10.22487/j24775398.2017.v 3.i3.9335

Mappiratu. (1997). Isolasi Mikroba Penghasil Enzim Protease, Amilase dan Lipase Serta Pengujian Potensi Produksinya. [Tesis]. Institut Pertanian Bogor, Bogor.

Pasaribu, S., Hamid, H., \& Sinurat, A. (1998). Fermetasi Bungkil Inti Sawit Secara Substrat Padat dengan Menggunakan Aspergillus niger. Balai Penelitian Ternak, Bogor.

Prabaningtyas, R. K., Putri, D. N., Utami, T. S., \& Hermansyah, H. (2018). Production of Immobilized Extracellular Lipase from Aspergillus niger by Solid State Fermentation Method Using Palm Kernel Cake, Soybean Meal, and Coir Pith as The Substrate. Energy Procedia, 153: 242247.

https://doi.org/10.1016/j.egypro.2018.10.010

Prihatini, R. (2008). Analisa Kecukupan Panas Pada Proses Pasteurisasi Santan. [Skripsi]. Institut Pertanian Bogor, Bogor.

Purkan, P., Purnama, H., \& Sumarsih, S. (2016). Production of Cellulase Enzyme from Aspergilus niger using Rice Husk and Bagasse as Inducer. Jurnal ILMU DASAR, 16(2):

95. https://doi.org/10.19184/jid.v16i2.2768

Putranto, R. A., Santoso, D., Tri-Panji, Suharyanto, \& Budiani, A. (2006). Karakterisasi Gen Penyandi Lipase dari 
Kapang Rhizopus oryzae dan Absidia corymbifera. E-Journal Menara Perkebunan, $\quad$ 74(1). https://doi.org/10.22302/iribb.jur.mp.v74i1. 118

Utami, T. S., Hariyani, I., Alamsyah, G., \& Hermansyah, H. (2017). Production of Dry Extract Extracellular Lipase from Aspergillus niger by Solid State Fermentation Method to Catalyze Biodiesel Synthesis. Energy Procedia, 136: 41-46. https://doi.org/10.1016/j.egypro.2017.10.2 75

Winarno, F. (2004). Kimia Pangan dan Gizi. Gramedia Pustaka Utama, Jakarta.

Zaks, A., \& Klibanov, A. (1984). Enzymatic Catalysis in Organic Media at 100 Degrees C. Science, 224(4654): 1249-1251. https://doi.org/10.1126/science.6729453 